\title{
Endothelial cell markers in coronary artery disease
}

Markery komórek śródbłonka w chorobie niedokrwiennej serca

\begin{abstract}
Magdalena Lampka1', Zofia Grąbczewska², Maria Krajewska1, Iga Hołyńska-Iwan¹, Jacek Kubica², Tomasz Tyrakowski
\end{abstract}
1Department of Pathobiochemistry and Clinical Chemistry, Nicolaus Copernicus University, Medical College, Bydgoszcz, Poland

2Department of Cardiology and Internal Diseases, Nicolaus Copernicus University, Medical College, Bydgoszcz, Poland

Postep Kardiol Inter 2012; 8, 4 (30): 275-279

DOI: $10.5114 /$ pwki.2012.31907

\begin{abstract}
Background: Endothelial injury, activation and dysfunction play an important role in atherosclerosis progression and development of cardiovascular disease.

Aim: To evaluate biochemical markers assessing the vascular endothelium state in patients with coronary artery disease.

Material and methods: We examined 57 patients with coronary artery disease (CAD): 27 patients with acute myocardial infarction (AMI) and 30 patients with stable angina pectoris (SA). The control group comprised 23 patients without symptoms of CAD. The concentration of von Willebrand factor (vWF), thrombomodulin (sTM), endothelin-1 (ET-1), and adhesion molecules (soluble intercellular adhesion molecule-1 (sICAM-1) and soluble vascular cell adhesion molecule-1 (sVCAM-1)) was analysed in plasma or serum.

Results: A significant increase in VWF, sICAM-1, sVCAM-1 and ET-1 concentrations was found in AMI compared to the control group. Increased vWF and sICAM-1 concentrations were found in SA compared to the control group. The AMI group was characterized by significantly higher VWF concentration than the SA group. Thrombomodulin concentration did not differ significantly between any patient groups and the control group. There was a positive correlation between VWF concentration and sVCAM-1 and sTM concentrations, and an inverse correlation between ET-1 and SICAM-1 concentrations in AMI. A sICAM-1 correlated positively with sVCAM-1 concentration in SA.

Conclusions: von Willebrand factor is more useful than STM, endothelin-1, and cell adhesion molecules sICAM-1 and sVCAM-1 to assess endothelium state in patients with CAD. The increase in plasma vWF concentration confirms endothelial injury and/or activation in CAD and indicates a greater severity of these disorders in AMI than in SA.
\end{abstract}

Key words: coronary artery disease, endothelial markers

\section{Streszczenie}

Wstęp: Uszkodzenie, aktywacja lub zaburzenie funkcji śródbłonka naczyniowego odgrywają ważną rolę w progresji zmian miażdżycowych i rozwoju chorób układu krążenia. serca.

Cel: Ocena wskaźników biochemicznych określających stan śródbłonka naczyń krwionośnych u osób z chorobą niedokrwienną

Materiat i metody: Badaniami objęto 57 osób z chorobą niedokrwienna serca (coronary artery disease - CAD): 27 pacjentów z ostrym zawałem serca (acute myocardial infarction - AMI) oraz 30 pacjentów ze stabilną chorobą wieńcową (stable angina - SA). Grupę kontrolną stanowiły 23 osoby bez objawów choroby wieńcowej. Stężenia czynnika von Willebranda (von Willebrand factor VWF), trombomoduliny (thrombomodulin - sTM), endoteliny-1 (endothelin-1 - ET-1), cząsteczek adhezyjnych [międzykomórkowej (soluble intercellular adhesion molecule-1 - sICAM-1) i naczyniowej (soluble vascular cell adhesion molecule-1 - sVCAM-1)] oznaczano w osoczu lub surowicy.

Wyniki: U pacjentów z AMI obserwowano istotnie zwiększone w stosunku do grupy kontrolnej stężenia vWF, sICAM-1, sVCAM-1 i ET-1. U osób z SA stężenia vWF i sICAM-1 były istotnie większe w stosunku do grupy kontrolnej. U pacjentów z AMI występowały istotnie większe stężenia vWF niż u osób z SA. Stężenia sTM w żadnej z badanych grup pacjentów nie różniły się od stężeń w grupie kontrolnej. U osób z AMI obserwowano istotną dodatnią korelację pomiędzy stężeniami vWF a sVCAM-1 i sTM oraz ujemną korelację pomiędzy stężeniami ET-1 a sICAM-1. W grupie pacjentów z SA występowała dodatnia korelacja pomiędzy stężeniami sICAM-1 a sVCAM-1.

Corresponding autor/Adres do korespondencji:

Magdalena Lampka MD, PhD, Department of Pathobiochemistry and Clinical Chemistry, Nicolaus Copernicus University, Medical College,

9 Curie-Skłodowskiej St, 85-094 Bydgoszcz, Poland, tel. +48 5258535 97, e-mail: lampka@cm.umk.pl

Praca wpłynęła: 23.08.2012, przyjęta do druku: 13.09.2012. 
Wnioski: Czynnik von Willebranda jest bardziej użyteczny w ocenie stanu śródbłonka naczyniowego u osób z chorobą niedokrwienną serca niż sTM, ET-1, sICAM-1 i sVCAM-1. Zwiększenie stężenia vWF potwierdza uszkodzenie i/lub aktywację śródbłonka naczyniowego u pacjentów z chorobą niedokrwienną serca i wskazuje na większe nasilenie tych zaburzeń w zawale mięśnia sercowego niż w stabilnej chorobie wieńcowej.

Słowa kluczowe: choroba niedokrwienna serca, markery śródbłonka

\section{Background}

Dysfunction, activation and injury of endothelium play an important role in the progression of atherosclerosis and the onset of cardiovascular diseases. Endothelial cell markers released to the circulation from the surface or from granules of these cells may be determined by means of laboratory methods and used to assess the severity of abnormalities of the endothelial layer. Endothelial injury leads to anatomical changes and separation of endothelial cells from the basal membrane [1]. The most frequently used biochemical markers of endothelial injury include von Willebrand factor (VWF) and thrombomodulin (TM). Von Willebrand factor is a glycoprotein stored in the Weibel-Palade bodies of the endothelium. It takes part in platelet adhesion to the injured vascular wall and in the process of platelet aggregation during thrombus formation. Thrombomodulin is a transmembrane glycoprotein of the endothelial cells with antithrombotic activity. Thrombomodulin may be released from the surface of endothelial cells and circulate in blood in the soluble form (STM) [2, 3]. Activation of endothelial cells is related to increased expression of adhesion molecules on their surface, which cause leucocyte adhesion to the vascular wall and penetration of these cells into the subendothelial layer. This initiates inflammatory processes in the vascular wall, which lead to the formation of atheroma. Adhesion molecules taking part in the transmigration of leucocytes include vascular cell adhesion molecule-1 (VCAM-1) and intercellular adhesion molecule-1 (ICAM-1). Activated adhesion molecules undergo desquamation from the cellular surface and appear in the circulation in soluble forms: SVCAM-1 and sICAM-1, which are potential markers of endothelial cell activation [3, 4]. Endothelial dysfunction is the loss of functional integrity characterized by disequilibrium between vasodilatative and vasoconstrictive factors and between antithrombotic and prothrombotic factors [3]. Markers of endothelial dysfunction include endothelin-1 (ET-1), which is considered as one of the main factors influencing vascular constriction. Endothelial cells are the main source of ET-1. The significance of ET-1 in the pathogenesis of atherosclerosis depends on its proinflammatory and immunomodulating properties. Increased concentration of ET-1 in plasma was found in coronary artery disease, especially unstable. The role of endothelin in the onset of ischemic heart disease is determined by its direct vasoconstrictive effects and by stimulation of smooth muscle cell proliferation $[5,6]$. The newest endothelial markers include endothelial cells separated from the vascular wall and circulating in peripheral blood, which are an indicator of morphological injury $[7,8]$.

\section{Aim}

The aim of the study was to assess the biochemical markers determining endothelial status in patients with coronary artery disease.

\section{Material and methods}

\section{Study group}

The study group consisted of 57 patients with coronary artery disease (CAD): 27 patients with acute myocardial infarction (AMI) and 30 patients with stable angina pectoris (SA). The control group included 23 subjects without clinical symptoms of coronary artery disease. The Ethical Committee approved the protocol of the study.

\section{Laboratory tests}

Concentrations of biochemical markers of endothelial injury were determined with the ELISA method on the microplate reader Multiscan Ex, Labsystems. Concentrations of vWF (Asserachrom vWF, Roche Diagnostics, Poland) and TM (Imubind Thrombomodulin ELISA, American Diagnostica, Inc) were assessed in the citrated blood. Concentrations of ET-1 (Endothelin (1-21), Biomedica), VCAM-1 (Quantikine Human SVCAM-1, R\&D Systems) and ICAM-1 (human sICAM-1 ELISA from Bender MedSystems) were assessed in plasma.

\section{Statistical analysis}

Statistical analysis was performed with Statistica software from StatSoft. Concentrations of all assessed parameters were presented as medians as well as lower and upper quartile $\left(\mathrm{Q}_{25}-\mathrm{Q}_{75}\right)$. Kruskal-Wallis test was used for statistical analysis of differences between results in the study group and in the control group. Values with $p<0.05$ were considered statistically significant. Correlations between analysed parameters were determined by means of the Spearman correlation coefficient.

\section{Results}

Clinical characteristics of the groups of patients with AMI or SA and patients from the control group are presented in Table 1. Most of the patients in the AMI group had a diagnosis of ST-segment elevation myocardial infarction (STEMI), while the SA group included patients with 
Table 1. Clinical characteristics of patients with acute myocardial infarction (AMI), stable angina pectoris (SA) and control subjects (C)

Tabela 1. Charakterystyka kliniczna badanych pacjentów z zawałem mięśnia sercowego (AMI), stabilną chorobą wieńcową (SA) i osób z grupy kontrolnej (C)

\begin{tabular}{lccc} 
Parameter & AMI $(n=27)$ & SA $(n=30)$ & $C(n=23)$ \\
\hline Sex: women/men & $9(34 \%) / 18(66 \%)$ & $7(23 \%) / 23(77 \%)$ & $13(57 \%) / 10(43 \%)$ \\
\hline Age [years] & $62 \pm 11$ & $64 \pm 9$ & $53 \pm 13$ \\
\hline STEMI/NSTEMI & $23(85 \%) / 4(15 \%)$ & & \\
\hline CCS class II of angina pectoris & & & \\
\hline Troponin I $[\mathrm{ng} / \mathrm{ml}]$ & $0.73(0.29-6.29)$ & $4(100 \%)$ & $0(0 \%)$ \\
\hline BMI $>30 \mathrm{~kg} / \mathrm{m}^{2}$ & $7(26 \%)$ & $12(40 \%)$ & $2(9 \%)$ \\
\hline Hypertension & $16(59 \%)$ & $3(10 \%)$ & $0(0 \%)$ \\
\hline Diabetes & $4(15 \%)$ & $10(33 \%)$ & $5(23 \%)$ \\
\hline Smoking & $13(48 \%)$ & $6(19 \%)$ & $16(70 \%)$ \\
\hline Cholesterol $>200 \mathrm{mg} / \mathrm{dl}$ & $13(48 \%)$ & $3(10 \%)$ & $1(4 \%)$
\end{tabular}

Table 2. Concentrations of endothelial cell markers in patients with acute myocardial infarction (AMI), stable angina pectoris (SA) and control subjects (C)

Tabela 2. Stężenia markerów komórek śródbłonka u pacjentów z zawałem mięśnia sercowego (AMI), stabilną chorobą wieńcową (SA) i osób z grupy kontrolnej (C)

\begin{tabular}{lcccc} 
Endothelial cell marker & AMI & SA & C & Value of $p$ \\
\hline VWF $[\%]$ & $182(153-202)$ & $123(108-146)$ & $89(70-115)$ & $<0.001^{*},<0.01^{\star *},<0.001^{\#}$ \\
\hline STM $[\mathrm{ng} / \mathrm{ml}]$ & $3.02(2.68-3.57)$ & $3.09(2.71-3.33)$ & $2.69(2.34-3.07)$ & \\
\hline SVCAM-1 $[\mathrm{ng} / \mathrm{ml}]$ & $673(601-822)$ & $626(574-703)$ & $598(552-661)$ & $<0.05^{*}$ \\
\hline sICAM-1 $[\mathrm{ng} / \mathrm{ml}]$ & $310(267-407)$ & $322(250-366)$ & $247(207-271)$ & $<0.01^{*},<0.05^{\star *}$ \\
\hline ET-1 $[\mathrm{fmol} / \mathrm{ml}]$ & $0.63(0.31-0.96)$ & $0.37(0.20-0.66)$ & $0.13(0.06-0.85)$ & $<0.05^{*}$
\end{tabular}

Statistically significant difference between groups * $A M I$ and $C$, ${ }^{*} S A$ and $C,{ }^{*} A M I$ and $S A$.

Statystycznie istotna różnica pomiędzy grupami *AMI i C, ${ }^{* *} S A$ i $C$, ${ }^{*} A M I$ i SA.

CCS class II angina. Table 1 also shows the concentration of troponin I (TnI) in the AMI group and the prevalence of risk factors of CAD in both study groups and in the control group.

Patients in the AMI group had significantly higher concentrations of VWF ( $p<0.001)$, sICAM $(p<0.01)$, sVCAM-1 $(p<0.05)$ and ET-1 $(p<0.05)$ in comparison to the control group. Patients in the SA group had significantly higher concentrations of VWF $(p<0.01)$ and SICAM-1 $(p<0.05)$ in comparison to the control group. Patients in the AMI group were characterized by significantly higher concentration of vWF ( $p<0.001)$ than those in the SA group. Thrombomodulin concentrations were similar in both study groups and in the control group (Table 2).

Statistical analysis of the AMI group demonstrated a significant and positive correlation between vWF concentration and SVCAM and TM concentrations and a negative correlation between ET-1 and SICAM-1 concentration. In the SA group sICAM-1 positively correlated with SVCAM-1 concentration (Table 3 ). In the group of all patients with CAD there was a positive correlation $(p<0.05)$ between VWF concentration and white blood cell count (Fig. 1).

\section{Discussion}

In patients with coronary artery disease VWF best identifies endothelial disorders of all the analysed biochemical markers. Concentration of this parameter is increased in patients with $\mathrm{AMI}$ and in patients with SA in comparison to the control group. Higher levels of VWF in AMI than in SA indicate more severe endothelial disorders. Data from

Table 3. Correlations between endothelial cell markers in patients with acute myocardial infarction (AMI) and stable angina pectoris (SA)

Tabela 3. Korelacje pomiędzy markerami komórek śródbłonka u pacjentów z zawałem mięśnia sercowego (AMI) i stabilna chorobą wieńcową (SA)

\begin{tabular}{lcc}
\multirow{2}{*}{$\begin{array}{l}\text { Endothelial } \\
\text { cell marker }\end{array}$} & \multicolumn{2}{c}{ Correlation coefficient $r(p<0.05)$} \\
\cline { 2 - 3 } & \multicolumn{1}{c}{ AMI } & SA \\
\hline VWF & sVCAM-1: $r=0.4336$ & \\
\hline STM & VWF: $r=0.4544$ & sVCAM-1: $r=0.5706$ \\
\hline SICAM-1 & & \\
\hline ET-1 & sICAM-1: $r=-0.479$ &
\end{tabular}






Fig. 1. Correlation between von Willebrand factor concentration (VWF) and white blood cell count (WBC) in patients with coronary artery disease (CAD, $n=57$ )

Ryc. 1. Korelacje pomiędzy stężeniem czynnika von Willebranda (VWF) a liczba leukocytów (WBC) $w$ grupie pacjentów z chorobą niedokrwienna serca $(C A D, n=57)$

the literature confirm the increase of vWF concentration in various forms of CAD, with the highest values observed in myocardial infarction $[1,3,9,10]$. Increased concentration of VWF in plasma may be not only a marker of endothelial injury, but also a marker of its activation and dysfunction [2]. The positive correlation between the level of this parameter and white blood cell count found in the group of all patients with CAD confirms the role of VWF as a marker of endothelial activation. The positive correlation between VWF concentration and the number of circulating endothelial cells in the same group of patients with CAD in previously published reports confirms the role of VWF as a marker of endothelial injury. In the reported studies an increased number of circulating endothelial cells indicating morphological injury was found only in the AMI group [8]. It seems that increased concentration of VWF in the AMI group is mainly caused by endothelial injury and in the SA group by endothelial activation. In patients with AMI von Willebrand factor could also have been released to the circulation from activated platelets, which take part in thrombus formation on the ruptured atherosclerotic plaque. However, the positive correlation found in the AMI group between VWF concentration and SVCAM-1, which is not present on the platelet surface, indicates that injured endothelium is the main source of VWF released to the circulation during acute coronary events. In the presented studies STM turned out to have low sensitivity in detection of endothelial injury. This parameter was not statistically increased in any of the groups. Data from the literature demonstrate increased, decreased and unchanged concentrations of STM in patients with CAD $[2,9,11]$. The discrepancy between these results may be an effect of synergy between two opposing mechanisms: increased release of STM from the endothelium caused by currently acting damaging factors and decreased TM expression from the whole endothelial surface in patients with coronary artery disease. In vitro studies showed that TM expression on the endothelium is suppressed by inflammation and ischaemia [2]. Chong et al. demonstrated lower sensitivity of STM than VWF in the assessment of severity of endothelial injury in patients with chronic heart failure [12]. However, in the present study STM concentration in patients with AMI correlated with vWF concentration, which suggests parallel release of these two markers to the circulation during acute coronary events. Increased concentration of sICAM-1 in both groups of patients with CAD indicates increased endothelial activation and intensification of chronic inflammatory processes in the vascular wall. Lack of differences in SICAM-1 concentration between the AMI and SA groups does not allow one to differentiate the severity of endothelial activation in these two forms of CAD. Studies by other authors confirm changes of sICAM-1 concentration presented in this study or do not demonstrate an increased concentration of this parameter in CAD or show higher values in AMI than in SA $[4,13,14]$. Acute coronary events cause an increase of VCAM-1 and ET-1 concentrations in plasma. The increased SVCAM-1 concentration observed in our study only in patients with myocardial infarction may be a marker of intensified inflammatory processes occurring mainly in the injured atherosclerotic plaque. In the present study the concentration of the endothelial dysfunction marker ET-1 is higher only in the AMI group and remains unchanged in the SA group in comparison to the control group. Literature data confirm the presence of increased ET-1 concentration in unstable angina and in myocardial infarction. Increased levels of ET-1 in myocardial infarction reflect its vasoconstrictive actions. The main sources of intensified production of ET-1 in myocardial infarction include infarct-related coronary arteries, pulmonary vessels, left ventricle and peripheral circulation [5]. The presented results showed a negative correlation between ET-1 and SICAM-1 concentration in patients with AMI, which may suggest decreased production of endothelin with increasing endothelial activation. This relation is rather unexpected and requires confirmation in further studies. The results of experimental studies demonstrate that ET-1 promotes proinflammatory reactions, which stimulate endothelial expression of VCAM-1 [6]. Biochemical markers have different specificity in the assessment of endothelial status. The most specific ones are VWF and TM. It is assumed that endothelial cells are the main source of these molecules in the circulation and that the presence of vWF and TM in platelets does not influence their blood pool $[2,10]$. Lower specificity as endothelial cell markers was found for SICAM-1 and SVCAM-1, which are also present on myocytes and fibroblasts of the vascular wall, and in the case of ICAM-1 also on circulating blood cells: platelets, 
monocytes and lymphocytes. According to Güray et al. increased concentration of SICAM-1 in patients with SA may be caused by release of this molecule also from the cells circulating in peripheral blood [14]. In our study concentration of SICAM-1 in plasma of patients with SA correlated positively with sVCAM-1 levels, suggesting a significant role of vascular wall cells in the release of ICAM-1 to the circulation. Endothelin-1 is synthesized in many types of cells and seems to be a marker of endothelial dysfunction of low specificity. However, it was demonstrated that endothelium and macrophages are its main source in plasma in patients with heart failure [2]. The conducted studies suggest that among analysed biochemical markers VWF is most useful in the assessment of endothelial status in the course of CAD. In patients with CAD increased $\checkmark W F$ concentration confirms injury and/or activation of the endothelium and indicates a more severe form of these disorders in myocardial infarction than in SA. Thrombomodulin is characterized by low sensitivity in the assessment of endothelial injury. The SICAM-1 concentration reveals an increase of endothelial activation in both forms of coronary artery disease, but cannot differentiate the severity of this process in myocardial infarction and stable angina. The SVCAM-1 and ET-1 concentrations in plasma increase in acute coronary events, but not in SA. An increase of SVCAM-1 concentration may be explained by intensification of inflammatory processes in the atherosclerotic plaque.

\section{Conclusions}

In patients with coronary artery disease VWF is more useful in the assessment of endothelial function in comparison to TM, ET-1 and adhesion molecules SICAM-1 and sVCAM-1. Increased VWF concentration confirms the presence of endothelial injury and/or activation in patients with CADe and indicates a more severe form of these disorders in myocardial infarction than in SA.

\section{References}

1. Lee KW, Lip GYH, Tayebjee M, et al. Circulating endothelial cells, von Willebrand factor, interleukin-6, and prognosis in patients with acute coronary syndromes. Blood 2005; 105: 526-532.

2. Chong AY, Blann AD, Lip GYH. Assessment of endothelial damage and dysfunction: observations in relation to heart failure. Q J Med 2003; 96: 253-267.

3. Constans J, Conri C. Circulating markers of endothelial function in cardiovascular disease. Clin Chim Acta 2006; 368: 33-47.

4. Mizia-Stec K, Zahorska-Markiewicz B, Mandecki T. Serum levels of selected adhesion molecules in patients with coronary artery disease. Int J Cardiol 2002; 83: 143-150.

5. Celiński R. Usefulness of endothelin-1 determinations in the diagnosis of cardiovascular diseases. Pol Merkuriusz Lek 2010; 28: 220-222.

6. Dobrek $t$, Thor P. Endothelin in cardiovascular diseases pathophysiology. Pol Merkuriusz Lek 2010; 28: 289-292.

7. Chong AY, Lip GYH, Freestone B, et al. Increased circulating endothelial cells in acute heart failure: comparison with von Willebrand factor and soluble E-selectin. Eur Heart J 2006; 8: 167-172.
8. Lampka M, Grąbczewska Z, Jendryczka-Maćkiewicz E, et al. Circulating endothelial cells in coronary artery disease. Kardiol Pol 2010; 68: 987-992.

9. Kotschy M, Żekanowska E, Rość D, et al. Does extracorporal circulation artery bypass graft damage vascular endothelial cells? Pol Merkuriusz Lek 2003; 15 135-139.

10. Spiel AO, Gilbert JC, Jilma B. Von Willebrand factor in cardiovascular disease: focus on acute coronary syndromes. Circulation 2008; 117: 1449-1459.

11. Morange PE, Simon C, Alessi MC, et al. Endothelial cell markers and the risk of coronary heart disease. The Prospective Epidemiological Study of Myocardial Infarction (PRIME) Study. Circulation 2004; 109: 1343-1348.

12. Chong AY, Blann AD, Patel J. Endothelial dysfunction and damage in congestive heart failure. Circulation 2004; 110: 1794-1798.

13. Postadzhiyan AS, Tzontcheva AV, Kehayov I, et al. Circulating soluble adhesion molecules ICAM-1 and VCAM-1 and their association with clinical outcome, troponin $\mathrm{T}$ and $\mathrm{C}$-reactive protein in patients with acute coronary syndromes. Clin Biochem 2008; 41: 126-133.

14. Güray U, Erbay AR, Güray Y, et al. Levels of soluble adhesion molecules in various clinical presentations of coronary atherosclerosis. Int J Cardiol 2004; 96: 235-240. 